\section{UNIVERSITY \\ of DEBRECEN}

FACULTY OF

HeAlth

NYíreGYHÁZA

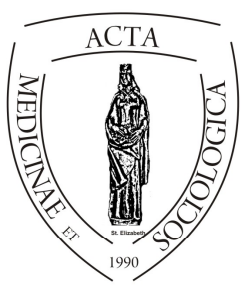

ACTA

MedSoc

VOLUME 6.

2015

\title{
A pszichológiai jóllét és az azt meghatározó tényezők összefüggéseinek nemzetközi vizsgálata felsőoktatásban tanuló fiatalok körében
}

\author{
Barth Anita
}

Debreceni Egyetem Egészségügyi Kar

\begin{abstract}
The aim of this study is a more accurate characterization and identification of students with mental health factors, which could help to improve mental health in the context of higher education. The research was conducted at the University of Debrecen, the Partium Christian University and the State University of Oradea among students. The questionnaire examined the demographic data, the depression, anxiety and stress (DASS21), the psychological wellbeing (Ryff-18) and the conflict management strategies (TKI). Two questionnaires (DASS-21, Ryff-18) are under validation in Hungary. The sample $(\mathrm{N}=237)$ consisted of 147 students from University of Debrecen and 90 students from the State University of Oradea and Partium Christian University. Result of the research showed that there is significant difference in autonomy $(p=0,005)$ and purpose in life $(\mathrm{p}=0,018)$. I also found significant difference in the negative emotional states of stress $(p=0,042)$ among students. The students from University of Debrecen reach higher stress level. Furthermore I did not found differences in the conflict management strategies. The students prefer the avoiding conflict strategy.
\end{abstract}

Keywords: psychological wellbeing, stress, international research, higher education 
Absztrakt. Kutatásom célja a hallgatók lelki egészségének pontosabb jellemzése és olyan tényezők azonosítása, amelyek segítségével a lelki egészséget javítani lehetne a felsőoktatás keretein belül. Ennek érdekében kérdőíves vizsgálatot végeztem a Debreceni Egyetem, a Partiumi Keresztény Egyetem és a Nagyváradi Állami Egyetem hallgatóinak körében. Kutatási módszerként a standard kérdőíves vizsgálatot választottam. Az általam használt kérdöív három standard eljárást tartalmazott: a Ryff - féle pszichés jóllétre vonatkozó kérdőívet, a mentális állapotot vizsgáló DASS kérdőívet valamint Thomas Kilmann konfliktuskezelési tesztjét. Az adatfeldolgozás SPSS program segítségével történt. A teljes minta 237 fős lett, 147 fö a Debreceni Egyetemröl, míg 90 fő a két nagyváradi egyetemröl. A Debreceni Egyetemen tanuló fiatalok $(\mathrm{N}=147)$ és a nagyváradi hallgatók $(\mathrm{N}=90)$ összehasonlítása során szignifikáns különbséget találtam a pszichés jóllét egyes összetevői közül az autonómia és az életcél területén. A mentális distressz mutatók közül pedig a stressz skálán mértem jelentős eltérést. Míg a Debreceni Egyetem hallgatói a mérsékelt, addig nagyváradi hallgatók az enyhe tartományba tartoznak a stressz tekintetében. A konfliktuskezelési stratégiák alkalmazásában nem találtam jelentős különbséget a két ország hallgatói között. A magyarországi és az erdélyi hallgatók egyaránt az elkerülő stratégiát preferálják.

Kulcsszavak: pszichológiai jóllét, stressz, felsőoktatás

\section{Bevezetés}

Az elmúlt évtizedekben egyre nyilvánvalóbbá vált, hogy a társadalmi és gazdasági változások gyakran káros hatással vannak az emberi személyiség fejlődésére. A technika és a tudomány fejlödése, az emberi látókör kitágulása, a történelmi változások egyre inkább előtérbe hozzák az ember lelki egyensúlyának, egészségének a fontosságát, hiszen a fizikai biztonság, az anyagi jólét és a megfelelö fejlődéshez szükséges helyzetek megteremtése még nem feltétlenül jelenti azt, hogy a fiatalok boldogok és elégedettek is az életükkel. Fokozatosan jelent meg az igény, hogy a fiatalok fejlödését szolgáló főbb szocializációs közegek, mint például az oktatási intézmények a boldog és elégedett életet is biztosítsák. A jelenlegi oktatási intézmények legtöbbször inkább stresszforrás és a félelemteli, mintsem a boldog élet egyik színterei [Hunter és Csikszentmihályi (2003) ld. még Hamvai és Pikó (2009)].

Témaválasztásomban szerepet játszott, hogy a Debreceni Egyetem Egészségügyi Karának ápoló szakos hallgatójaként nap, mint nap szembesülök azzal, hogy a felsőoktatásban eltöltött évek, sőt már maga az oda kerülés folyamata is számos stresszforrást rejt magában. A felsőoktatásba bekerülő fiatalok számos kihívással néznek szembe. Elöször is be kell illeszkedniük egy új közegbe, meg kell tanulniuk a tanulmányi ügyintézés menetét, kollégiumban, albérletben kipróbálják az önálló élet nehézségeit. Nyugtalanítóan hathat a számonkérések megterhelő iz- 
galma, a szoros határidők, a követelményeknek való elégtétel, a mindennapos konfliktusok. Nyomasztó érzés, ugyanakkor kihívás is megfelelni az esetleges szülöi, oktatói elvárásoknak. Ezeket a stresszhelyzeteket pedig nem mindenki tudja megfelelő módon kezelni. Kezeletlenül pedig negatívan befolyásolja a jóllétet, az életminőséget, sőt akár testi és lelki betegségek kialakulásához is vezethet. Több tanulmány is alátámasztja (Hazag és Major 2008; Móczár 2012; Lazányi 2011a), hogy napjainkban egyre nagyobb azoknak a felsőoktatásban tanuló fiataloknak az aránya akik, valamilyen lelki vagy pszichoszomatikus betegséggel küzdenek. Ennek ellenére a probléma megoldása máig elmaradt. Ugyan kisebb próbálkozások vannak különböző mentálhigiénés programok formájában, de azok, akik a leginkább érintettek nem jutnak el ezekre. Feltételezésem szerint ennek egyik oka az, hogy a hallgatók nincsenek megfelelő módon (olykor egyáltalán) tájékoztatva ezekről a programokról.

Vizsgálatom célja a hallgatók lelki egészségének pontosabb jellemzése és olyan tényezők azonosítása, amelyek segítségével a lelki egészséget javítani lehetne a felsőoktatás keretein belül. Vizsgálatom eredményeivel egyrészt szeretnék hozzájárulni a fiatalok mentális egészségével foglalkozó primer prevenciós programok hatékonyságához és a velük foglalkozó szakemberek munkájához. Másrészt bővíteni szeretném a magyarországi validálás alatt álló Ryff-18 és DASS-21 kérdöívek adatbázisát. A DASS-21 kérdőív validálását Kósa Karolina és Tolvay Katalin (Debreceni Egyetem Népegészségügyi Kar, Magatartástudományi Intézet) végzik. A Ryff kérdőívet Kállay Éva és Dégi László Csaba (Kolozsvári Babeș Bólyai Tudományegyetem) fordították, a validálását pedig egy közös kutatócsoport elkezdte Magyarországon, melynek tagjai: Kállay Éva, Dégi László Csaba, Sass Judit, Bodnár Éva és Kiss János.

\section{Kutatási módszerek}

\section{Mintavétel és minta}

A kutatást a Debreceni Egyetem, a Partiumi Keresztény Egyetem és a Nagyváradi Állami Egyetem hallgatóinak körében végeztem. Az adatfelvétel a 2013/2014-es tanév II. félévében történt, önkitöltős, interneten kitölthető kérdőívvel. Azért döntöttem az elektronikus adatfelvétel mellet, mert a populációt alkotó egyének mindennapjainak elengedhetetlen része az internet. A kérdőívet aktív jogviszonnyal rendelkezö hallgatók tölthették ki. A teljes minta 237 fös lett: 147 fő a Debreceni Egyetemről, míg 90 fő a két nagyváradi egyetemről. 


\begin{abstract}
Alkalmazott mérőeszközök
Kutatási módszerként a standard kérdőíves vizsgálatot választottam, mert ezzel jelentősebb elemszámú minta megkérdezése is elvégezhető. Úgy vélem, hogy az engem leginkább érdeklő pszichés jóllétet, valamint az azt befolyásoló tényezőket szubjektív, önkitöltős kérdőívekkel lehet leginkább feltérképezni. A 76 itemből álló kérdőív a kérdéscsoportok alapján négy részre tagolható.
\end{abstract}

A megkérdezettek az első hét kérdés megválaszolásával az alapvető szociodemográfiai adatokra vonatkozó kérdésekre adták meg a választ, melyek a nemre, életkorra, felsőoktatási intézményre, szakirányra, évfolyamra, munkarendre és képzési szintre vonatkoztak.

A második rész a DASS kérdöívet tartalmazta. A Magyarországon még validálás alatt álló kérdöívet ausztrál kutatók fejlesztették ki. A kérdőív három negatív érzelmi állapotot mér fel: a depressziót, a szorongást és a stresszt. Minden skálához hét-hét kérdés tartozik. Az önjellemzős kérdőív négyfokú Likert - skálán pontozódik. A Likert - skálán bejelölhető kategóriák: 0-3, ahol a (0) Egyáltalán nem volt rám jellemző; a (3) Nagyon nagy mértékben/nagyon gyakran volt rám jellemző (Henry és Crawford 2005).

A kérdőívem harmadik része a még validálás alatt álló, 18 itemes Ryff Jóllét skála. Az önjellemzős kérdöívben az állítások hat faktorra - az autonómia, környezet uralása, személyes fejlődés, másokkal való jó kapcsolat, életcélok, önelfogadás - vonatkoznak. Minden faktorhoz három kérdés tartozik. A válaszok egy hatfokú Likert - skálán adhatók meg, és azt mutatják, mennyire jellemzőek egy adott személyre az adott tulajdonságok saját megítélése szerint. A Likert skálán bejelölhető kategóriák: 1-6, ahol az (1) Egyáltalán nem értek egyet; a (6) Erösen egyetértek (Ryff 1989).

Az utolsó része Kenneth W. Thomas és Ralph H. Kilmann által kidolgozott kérdőív, melynek célja az egyéni viselkedés vizsgálata konfliktushelyzetekben. A kérdőív 30 állítás párból áll és mind az öt konfliktuskezelési stratégiára - versengő, alkalmazkodó, elkerülő, problémamegoldó, kompromisszumkereső - ad egy-egy pontszámot. Ez a pontszám jelzi, hogy milyen gyakran választottuk az egyes megoldási lehetőségek közül az adott viselkedésmintát. Az eredmény a konfliktuskezelési módok dominanciáját, alkalmazásuk gyakoriságát adja meg (Thomas és Kilmann 1974). 


\section{Alkalmazott statisztikai módszerek}

A feldolgozást és az elemzést matematikai-statisztikai módszerekkel, SPSS (Statistical Package for Social Science) szoftver segítségével végeztem. Az elemzés során az alábbi mủveleteket hajtottam végre:

- átlag

- szórás

- gyakoriság

- kétmintás t-próba

- Mann-Whitney próba

- konfidencia intervallum számítás

- korrelációszámítás

\section{Eredmények}

Az eredmények bemutatása során először a minta egészére $(\mathrm{N}=237)$ vonatkozó megállapításokat ismertetem, majd ezután összevetem a kutatásban részt vevő két ország hallgatóinak mutatóit.

Mivel a két nagyváradi egyetemről a vártnál kevesebb kitöltött kérdőívem érkezett vissza, ezért arra a döntésre jutottam, hogy a két nagyváradi egyetem hallgatóit egy csoportként kezelem $(\mathrm{N}=90)$ és a vizsgálatban részt vevő két ország hallgatóit hasonlítom össze (nem pedig az egyetemek hallgatóit). Úgy gondolom, az összevonás két okból is megtehető. Egyrészt a kérdőívek csak magyar nyelven voltak elérhetőek, ezért feltételezem, hogy a nagyváradi populáció azon tagjai töltötték ki, akik a nyelvet értik és beszélik, vagyis a magyar kisebbséghez tartoznak Romániában. Másrészt mindkét egyetem Nagyváradon található, így a hallgatók bár külön egyetemen tanulnak, mégis ugyanazon városi légkörben élik mindennapjaikat, ugyanolyan szórakozási lehetőségeik vannak, nagyon sokszor pedig ugyanabba a baráti társaságba tartoznak. Mint Nagyváradon élő rokonokkal és barátokkal rendelkező személy ezt kint tartózkodásom során tapasztaltam is.

\section{Demográfiai jellemzők}

A teljes minta 62\%-a (147 fö) a Debreceni Egyetem, míg 38\%-a (90 fö) a Partiumi Keresztény Egyetem (53 fö) és a Nagyváradi Állami Egyetem (37 fö) hallgatója. A résztvevők 73\%-a (174 fö) nő, 27\%-a (63 fö) férfi. A válaszadók átlagéletkora 22 év. A legfiatalabb válaszadó 18 , a legidősebb 46 éves volt. A felmérésben részt vettek $90 \%$-a alapképzésben, $10 \%$-a mesterképzésben tanul. A nappali tagozatos hallgatók a minta $97 \%$-át teszik ki és mindössze 3\%-át a levelező tagozatosok. 
A résztvevők körében a tanult szakirányok szerint is megvizsgáltam a megoszlást. A segítő hivatást választó hallgatók a teljes minta körülbelül $65 \%$-át teszik ki. Ez azt jelenti, hogy többségük általános orvos, ápoló, mentőtiszt, szülésznő, védőnő, egészségügyi szervező, pszichológia és szociális munka szakos hallgató.

\section{Pszichológiai jóllét a felsőoktatásban}

A minta egészére vonatkozó megállapítások

A felmérésben részt vevő hallgatók pszichológiai jóllétének egyes összetevőit Ryff vizsgálatának eredményeivel hasonlítom össze (1. táblázat).

Ryff 321 különböző életkorú személynél vizsgálta a pszichés jóllét egyes összetevőit. Életkor szerint a középkorúak között többen értek el magasabb értékeket a vizsgált dimenziókon (életcél, autonómia) a fiatalabb vagy idősebb korosztályhoz képest. A környezet uralásának észlelt képessége nőtt az életkorral, míg a személyes növekedés magasabb volt a fiatal és középkorú válaszadók körében. Nem szerint a másokkal való jó kapcsolat és a személyes növekedés észlelése a nőknél magasabb volt, mint a férfiaknál (Ryff 1989).

\begin{tabular}{|c|c|c|}
\hline & $\begin{array}{c}\text { A kutatásom során kapott } \\
\text { átlageredmények }\end{array}$ & Ryff átlageredményei \\
\hline Személyes növekedés & 13,39 & 15,5 \\
\hline Életcél & 13,27 & 14 \\
\hline Pozitív kapcsolat másokkal & 12,82 & 12,5 \\
\hline Önelfogadás & 12,33 & 12,5 \\
\hline Autonómia & 12,25 & 13 \\
\hline Környezet uralása & 12,24 & 12,5 \\
\hline & $\mathrm{N}=237$ & $\mathrm{~N}=321$ \\
\hline
\end{tabular}

1. táblázat: A pszichés jóllét egyes összetevőinek átlaga.

A hat skála közül a személyes növekedés területen kaptam a legmagasabb értéket. Az általam mért érték (átlag: 13,39) azonban jóval alacsonyabb, mint Ryff eredménye (átlag: 15,5). A személyes növekedés dimenziójánál mért alacsonyabb pontszám jelentheti azt, hogy a hallgatók fejlödése stagnál, unottak az élet legtöbb területén, nem képesek új viselkedési modell alkalmazására.

A személyes növekedés az önelfogadással $(\mathrm{r}=0,545)$ és az életcéllal $(\mathrm{r}=0,577)$ mutat szoros kapcsolatot. Az ember egyik életcélja a személyes növekedés vi- 
szont csak az a személy képes megvalósítani önmagát, aki pozitív önképpel rendelkezik (Kopp és Martos 2011).

Az életcél dimenziójánál mértem a második legmagasabb értéket. Ez a pontszám (átlag: 13,27) azonban alacsonyabb, mint Ryff átlageredménye (átlag: 14,00), ami utalhat arra, hogy a vizsgált személyek nem terveznek, mert nem látják az irányt, nem érdekli őket a jövő.

Az életcél szoros együttjárást jelez a már említett személyes növekedéssel $(\mathrm{r}=0,577)$ valamint a másokkal való pozitív kapcsolattal $(\mathrm{r}=0,499)$. Ez nem meglepő, hiszen az életcélok azokra az ideálokra, állapotokra vagy tárgyakra vonatkoznak, melyeket az emberek a legfontosabbnak tartanak az életben. A szokásos életcélok közé pedig a kapcsolatok, a munka, a jómód, gazdagság, a tudás és a teljesítmény tartoznak (Martos 2010).

A hat skála közül a másokkal való pozitív kapcsolat skálán kaptam csak nagyobb átlagértéket (átlag: 12,82), mint Ryff (átlag:12,5). A skálán mért magasabb pontszám jelentheti azt, hogy a hallgatók társas kapcsolataikban empatikusan, őszintén, érdeklődően és megértően tudnak viszonyulni másokhoz.

Az önelfogadás jelenti a pozitív önképet, vagyis önmagunk elfogadását a jó és a rossz tulajdonságainkkal együtt. Ezen a területen a kapott eredményem (átlag: 12,33) közel azonos Ryff eredményével (átlag: 12,5).

Ez a dimenzió szoros kapcsolatot jelez a már említett személyes növekedéssel $(\mathrm{r}=0,545)$ valamint a környezet uralásával $(\mathrm{r}=0,536)$. Tehát az a személy, aki pozitív énképpel rendelkezik, jobban tud alkalmazkodni az esetleges környezeti változásokhoz, jobban ki tudja használni a környezete által nyújtott lehetőségeket.

$\mathrm{Az}$ autonómia dimenziójánál mértem az egyik legalacsonyabb értéket. Az eredményem (átlag: 12,5) Ryff eredményéhez (átlag: 13) képest is alacsony. Ez utalhat arra, hogy a felsőoktatásban tanuló fiatalokat külső elvárások, mások értékelései irányítják, mások segítsége nélkül képtelenek fontos döntések meghozatalára.

A vizsgálatban részt vevő valamennyi hallgató jóllét észlelése az autonómia területén egyik változóval sem függ össze nagymértékben.

A hat skála közül a környezet uralása területén kaptam a legalacsonyabb értéket, amelyközel azonos Ryff eredményével. Feltételezhető, hogy a hallgatók nehezen kezelik mindennapi problémáikat és úgy érzik képtelenek javítani a környezetükön. 


\section{A vizsgálatban részt vevő két ország hallgatóinak összehasonlítása}

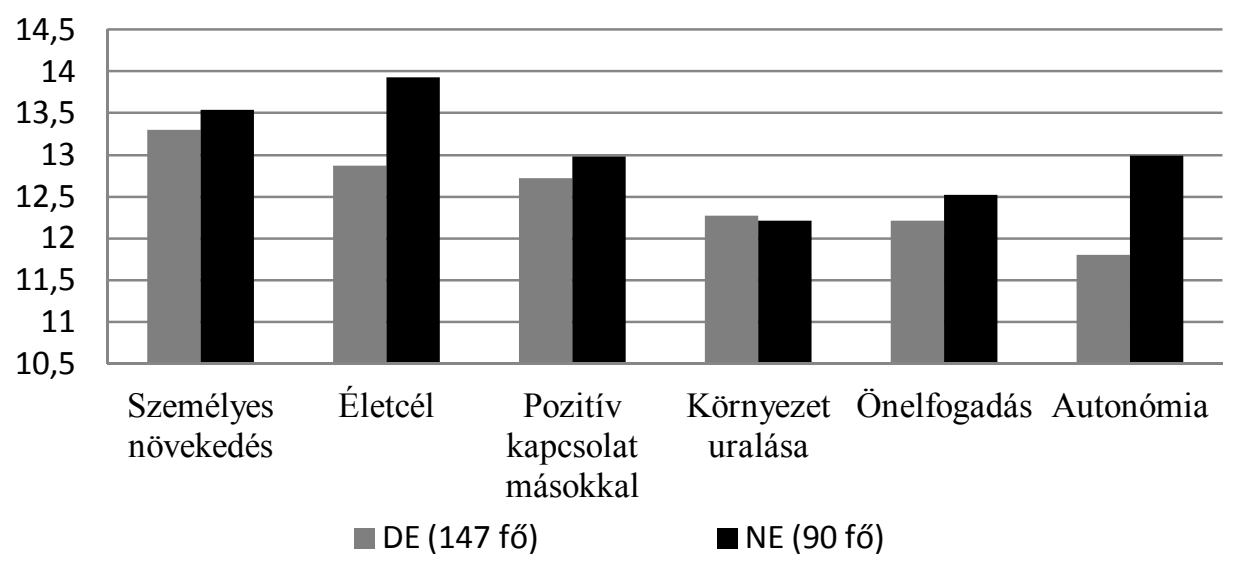

1. ábra: A pszichés jóllét egyes összetevőinek átlaga a vizsgált egyetemek hallgatóinak körében.

A hat faktor közül a személyes növekedés, a pozitív kapcsolat másokkal, a környezet uralása valamint az önelfogadás skálákon közel azonos eredményt kaptam.

Igen nagyok azonban a különbségek az életcél valamint az autonómia területén. A DE-en tanuló fiatalok életcélátlaga 12,87, a NE hallgatóinak átlaga 13,93. A kétmintás (független mintás) t-próba elvégzése során azt az eredményt kaptam, hogy a két átlageredmény között szignifikáns különbség van $(\mathrm{p}=0,018)$. Ebböl azt a következtetést lehet levonni, hogy a Nagyváradon található egyetemek hallgatóinak határozottabb céljaik vannak, hisznek a jelen és múltbeli életük értelmében és abban, hogy a céljaik megvalósulnak a jövőben. A DE-en tanuló fiatalok autonómiaátlaga 11,8, a NE hallgatóinak átlaga 12,99. A kétmintás (független mintás) $t$-próba eredménye $(p=0,005)$ alapján pedig elmondható, hogy a különbség erősen szignifikáns. Tehát a két nagyváradi egyetemen tanuló fiatalok saját standardjaik alapján értékelik önmagukat, társadalmi nyomás alatt is képesek önállóak maradni. 


\section{A hallgatók mentális distressz mutatói}

A minta egészére vonatkozó megállapítások

\begin{tabular}{|c|c|c|}
\hline & \multicolumn{2}{|c|}{ A kutatásom során kapott átlageredmények } \\
\hline & Átlag & Szórás \\
\hline Depresszió & 5,47 & 4,431 \\
\hline Szorongás & 4,34 & 3,662 \\
\hline Stressz & 8,54 & 4,683 \\
\hline \multicolumn{2}{|c|}{$\mathrm{N}=237$} \\
\hline
\end{tabular}

2. táblázat: A DASS-21 kérdőív skáláinak átlaga, szórása.

\begin{tabular}{|c|c|c|c|}
\hline & Depresszió & Szorongás & Stressz \\
\hline Normál & $51,5 \%$ (122 fó) & $50,2 \%$ (119 fó) & $44,3 \%$ (105 fó) \\
\hline Enyhe & $16 \%$ (38 fö) & $17,7 \%$ (42 fö) & $14,8 \%$ (35 fó) \\
\hline Mérsékelt & $17,8 \%$ (42 fó) & $15,2 \%$ (36 fó) & $19,8 \%$ (47 fó) \\
\hline Súlyos & 7,7\% (18 fó) & $6,3 \%$ (15 fó) & $16 \%$ (38 fó) \\
\hline Extrém súlyos & $7 \%$ (17 fó) & $10,5 \%$ (25 fö) & $5,5 \%$ (12 fó) \\
\hline \multicolumn{4}{|c|}{$\mathrm{N}=237$} \\
\hline
\end{tabular}

3. táblázat: A mentális distressz mutatóin belüli értékek gyakorisága.

\section{Depresszió:}

A depresszió skálán kapott átlageredményem 5,47. A kapott átlag alapján elmondható, hogy a hallgatók enyhe mértékü depressziót jeleznek.

A gyakoriságvizsgálat eredménye szerint a hallgatók 67,5\%-a tartozik a normál-enyhe, míg 32,5\%-a a mérsékelt - súlyos - extrém súlyos tartományba.

A korrelációszámítás során azt az eredményt kaptam, hogy a depresszió nem jár együtt a szorongással, ugyanakkor erős kapcsolatban áll a stresszel.

\section{Szorongás:}

A szorongás skálán kapott eredményem (átlag: 4,34) alapján elmondható, hogy a hallgatók enyhe mértékü szorongást jeleznek.

A gyakoriságvizsgálat eredménye szerint a hallgatók 67,9\%-a tartozik a normál - enyhe, míg 32,1\%-a a mérsékelt - súlyos - extrém súlyos tartományba.

A korrelációszámítás során azt az eredményt kaptam, hogy a szorongás nem jár együtt a depresszióval, de összefügg a stresszel. 
Stressz:

A három skála közül a hallgatók a stresszre vonatkozó tünetekre adták a legtöbb pontszámot (átlag: 8,54), ami enyhe mértékü stresszt jelez.

A gyakoriságvizsgálat azt az eredményt mutatja, hogy a résztvevők 59,1\%-a tartozik a normál-enyhe, míg 40,9\%-a a mérsékelt - súlyos - extrém súlyos tartományba.

A nemek közötti összehasonlításban számottevő különbséget találtam. Míg a férfiak (átlag: 6,86) a normál, addig a nők (átlag: 9,16) a mérsékelt tartományba tartoznak a stressz tekintetében. Az átlageredmények közötti különbség erősen szignifikáns $(\mathrm{p}=0,001)$.

A vizsgálatban részt vevő valamennyi hallgató mentális distressz mutatói közül a stressz erős kapcsolatot mutat a depresszióval $(\mathrm{r}=0,616)$ és a szorongással $(\mathrm{r}=0,628)$. Ez tehát azt jelenti, hogy a magas stressz-szinttel rendelkező hallgatók magas depresszió és szorongás szinttel is rendelkeznek.

\section{A vizsgálatban részt vevő két ország hallgatóinak összehasonlítása}

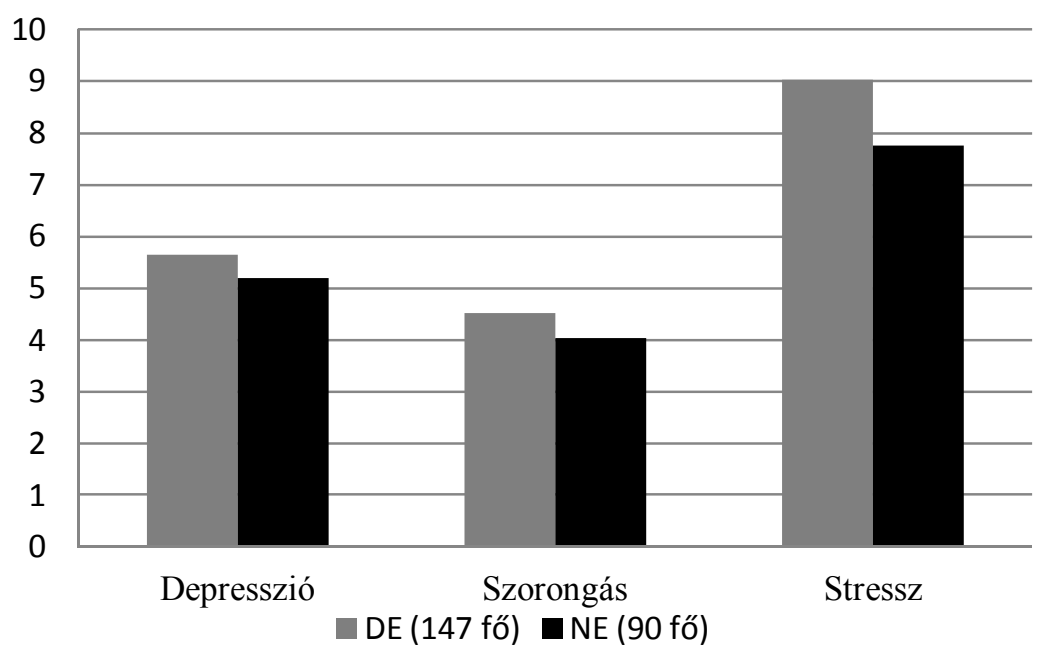

2. ábra: A hallgatók mentális distressz mutatói.

Összességében elmondható, hogy a DE hallgatói mindhárom skálán magasabb pontszámot értek el. Jelentős különbséget azonban csak a stressz skálán mértem. A DE-en tanuló fiatalok átlageredménye 9,03, míg a NE hallgatóinak eredménye 7,76. A paraméteres t-próba eredménye $(\mathrm{p}=0.042)$ alapján elmondható, hogy az átlagértékek különbsége szignifikáns. 
Úgy vélem ennek egyik oka a szakirányokban keresendő. A DE hallgatói között jóval nagyobb azoknak a fiataloknak az aránya, akik valamilyen segítő hivatást választottak maguknak. Továbbá a NE hallgatói közül 53 fö a keresztény értékrendủ egyetem hallgatója. A vallásról pedig számos kutatás bebizonyította, hogy megnyugvást nyújt és kedvezően befolyásolja az egészséget (Indiries 2005). Ezen kívül a NE hallgatói közül mindössze 90 fő vett rész a vizsgálatban, míg a DE hallgatói közül 147 fö töltötte ki a kérdőívet. Az egyenlötlen eloszlás pedig szintén okozhat eltérő eredményt. A két nagyváradi egyetem hallgatóinak az alacsonyabb stressz-szintje azonban utalhat arra is, hogy annak ellenére, hogy kisebbségben vannak még lehetőségük van önazonosságuk megörzésére, identitásuk kiteljesítésre.

\section{A konfliktuskezelési stratégiákkal kapcsolatos eredmények}

\section{A minta egészére vonatkozó megállapítások}

\begin{tabular}{|l|c|}
\hline & $\begin{array}{c}\text { A kutatásom során kapott } \\
\text { átlageredmények }\end{array}$ \\
\hline Versengő & 5,31 \\
\hline Problémamegoldó & 5,92 \\
\hline Alkalmazkodó & 5,95 \\
\hline Kompromisszumkereső & 6,11 \\
\hline Elkerülö & 6,7 \\
\hline & $\mathrm{N}=237$ \\
\hline
\end{tabular}

4. táblázat: A konfliktuskezelési stratégiák átlaga

Az öt konfliktuskezelési stratégia közül a versengés területen kaptam a legalacsonyabb értéket (átlag: 5,31). Ez azt jelenti, hogy a hallgatók nem akarják mindenáron a saját akaratukat érvényesíteni másokéval szemben, nem törekednek mindenáron a győzelemre. A nemek közötti összehasonlításban azt az eredményt kaptam, hogy a férfiak átlageredménye nagyobb, mint a nőké (átlag: 5,92 > 5,09). Annak eldöntésére, hogy szignifikáns-e a különbség a nem-paraméteres Mann-Whitney próbát alkalmaztam, melynek eredménye $(\mathrm{p}=0,075)$ alapján elmondható, hogy nincs szignifikáns különbség a nemek között. A konfliktuskezelési stratégiák közül egyedül a versengő stratégia mutat korrelációt más stratégiával. Erős negatív korrelációt jelez az alkalmazkodó stratégiával $(\mathrm{r}=-0,63)$. Ez tehát azt jelenti, hogy azok a hallgatók, akik magas átlageredményt értek el a versengő stratégia területén, azok alacsonyabb értékkel rendelkeznek az alkalmazkodás tekintetében. 
A legmagasabb átlageredményt az elkerülő konfliktuskezelési stratégia területén kaptam. Ez alapján tehát elmondható, hogy a fiatalok többsége a konfliktusokról azt gondolja, hogy jobb kimaradni belőle. A konfliktust inkább hárítják, elfojtatják, elkerülik úgy, hogy saját céljaikat, érdekeiket nem érvényesítik, ugyanakkor nem müködnek együtt a másik céljának elérése érdekében sem, így ez vesztes vesztes megoldásnak tekinthető. A nyugalom és csend érdekében inkább visszahúzódnak, hogy elhárítsák a fenyegető helyzetet. A teljes mértékủ passzivitással azonban másokat is gátolnak abban, hogy valamilyen elfogadható megoldás születhessen. Ez a konfliktuskezelési mód leginkább akkor használatos, amikor valaki kevés információval rendelkezik, és abban bízik, hogy az idő múlásával több információhoz juthat.

Kenneth W. Thomas és Ralph H. Kilmann által kidolgozott modell előnye egyrészt, hogy lehetőséget ad az egyéni konfliktuskezelési stratégiák mérésére, másrészt megmutatja, hogy az adott megközelítési mód mely helyzetben tekinthető hatékonynak. Fontos tudni, hogy nincs ,jó” vagy „rossz” megoldás. Mindenkinél előfordul mind az öt, a különbség csak az arányokban van. Minden embernek van azonban egy preferált stratégiája, amelynek ismerete segítheti az egyént abban, hogy melyik terület használata jellemzi és melyik az amelyiket esetleg fejlesztenie kéne. Egy-egy stratégia megjelenése nem minősít önmagában senkit, ezek megítélése csak az adott összefüggésrendszerben, az adott konkrét szituáció ismeretében lehetséges

\section{A vizsgálatban részt vevő két ország hallgatóinak összehasonlítása}

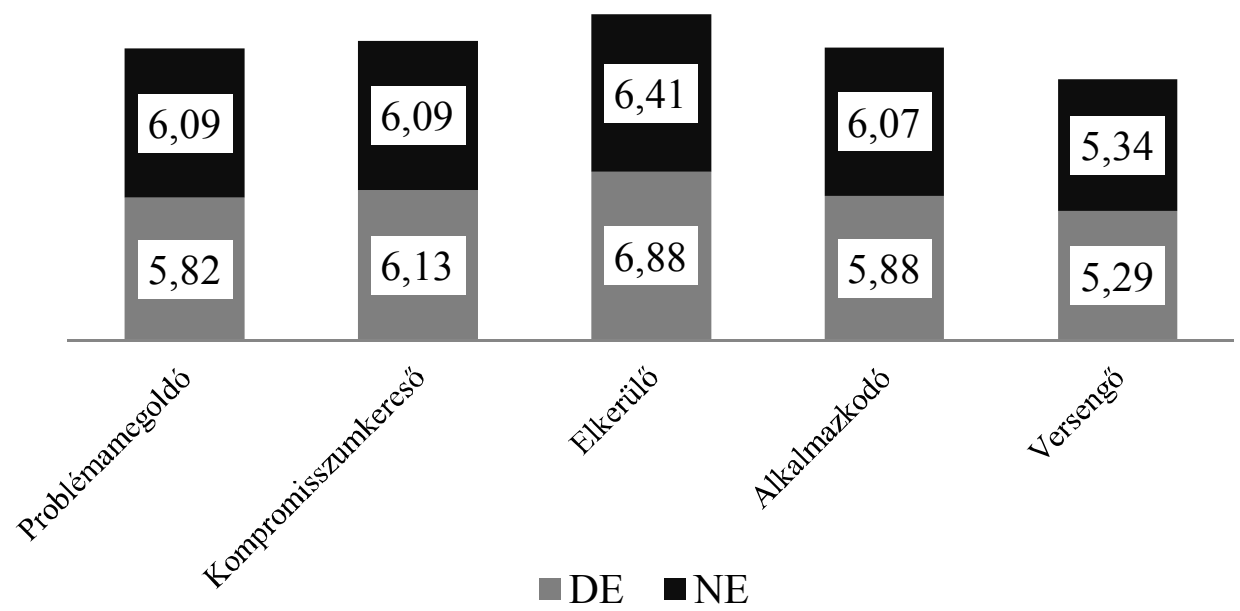

3. ábra: A hallgatók által alkalmazott konfliktuskezelési stratégiák átlaga. 
A 3. ábráról leolvasható, hogy a hallgatók átlageredményei között minimális különbségek vannak. A legtöbb pontszámot az elkerülö, míg a legkevesebbet a versengő konfliktuskezelési stratégia kapta mindkét ország hallgatóinak körében. Vagyis a hallgatókat alacsony önérvényesítés és együttmüködés jellemzi. A 95\%-os megbízhatósági szintű konfidencia intervallum figyelembe vételével azonban az is elmondható, hogy míg a Debreceni Egyetem hallgatóinál az elkerülö konfliktuskezelési stratégia minimum (átlag: 6,49) és maximum (átlag: 7,27) átlaga nem mutat átfedést a többi konfliktuskezelési stratégia minimum és maximum átlagával, tehát a többitől teljesen elkülönül, addig a nagyváradi hallgatóknál ez nem figyelhető meg.

\section{Javaslatok}

Mit tehetnek a felsőoktatási intézmények annak érdekében, hogy segítsék a hallgatókat a különböző stressz- és konfliktushelyzetek megoldásában?

Elöször is nagyon fontos tisztázni, hogy a stressz elkerülhetetlen. A stresszt csak kezelni lehet. Ebből kifolyólag úgy vélem, nagyon fontos lenne, hogy a hallgatók megfelelő megküzdési stratégiákkal rendelkezzenek. Különböző stresszkezelő tréningeken, kurzusokon a hallgatók el tudnák sajátítani azokat a módszereket, stratégiákat, technikákat, amelyek segítenének nekik abban, hogy hatékonyabban kezeljék a stresszt. Ezeket a kurzusokat akár szabadon választható tárgyként is meglehetne hirdetni, hiszen a hallgatókat a kurzus elvégzése után kapott néhány kredit is motiválná.

A tréningek hatékonyságát pedig kérdőíves felméréssel lehetne eldönteni, mely akár egy újabb kutatás alapjául is szolgálhatna.

Ezen kívül szakemberek bevonásával változatos sportolási lehetőségeket is lehet kínálni a hallgatók számára. Köztudott, hogy a rendszeres testmozgás az egészségi állapot szubjektív megítélését pozitív irányba befolyásolja, vagyis a hallgatók önértékelés, önbizalma ezáltal javulhatna. A rendszeres fizikai aktivitás csökkenti a feszültséget és azt az érzést erősíti az egyénben, hogy uralja a testét, ezzel együtt az életét.

Továbbá a felsőoktatási intézményeknek érdemes lenne alkalmazni illetve támogatnia a társas támogatás különböző formáit, mint például a szakkollégiumokat. A társas támogatás, mint a jóllét szükségszerü eleme, segít a stressz-szint csökkentésében valamint a megfelelő megküzdési módok kialakításában. Kutatások bizonyítják, hogy azok az emberek, akik széles támogatói körrel rendelkeznek, 
gyakrabban állnak pozitívan a felmerülő problémákhoz és könnyebben feledkeznek meg a negatív érzelmeikről (Lazányi 2011b).

Mindemellett már a felsőoktatásban el lehetne kezdeni a kiégés prevenciót a személyiség fejlesztésével, a szakmához kapcsolódó érzelmi követelmények megvilágításával.

\section{Összegzés}

Kutatásom célja a hallgatók lelki egészségének pontosabb jellemzése és olyan tényezők azonosítása, amelyek segítségével a lelki egészséget javítani lehetne a felsőoktatás keretein belül. Ennek érdekében kérdőíves vizsgálatot végeztem a Debreceni Egyetem, a Partiumi Keresztény Egyetem és a Nagyváradi Állami Egyetem hallgatóinak körében. A teljes minta 237 fös lett: 147 fö a Debreceni Egyetemről, míg 90 fö a két nagyváradi egyetemröl.

Kutatási módszerként a standard kérdőíves vizsgálatot választottam. A 46 itemből álló kérdőív a kérdéscsoportok alapján három részre tagolható. Az első rész a szociodemográfiai adatokra vonatkozó kérdéseket tartalmazta, a második rész a DASS-21 kérdőívet, amely három negatív érzelmi állapotot mér fel: a depressziót a szorongást és a stresszt. Az utolsó rész Ryff Jóllét skálája, amelyben az állítások hat faktorra - autonómia, környezet uralása, személyes fejlődés, másokkal való jó kapcsolat, életcélok, önelfogadás - vonatkoznak. A feldolgozást és az elemzést SPSS program segítségével végeztem. Eredményeim a következőképpen alakultak: A vizsgálatban részt vevő hallgatók $(\mathrm{N}=237)$ a személyes növekedés területén érték el a legmagasabb átlageredményt, míg a két legalacsonyabbat az autonómia és a környezet uralása skálákon mértem. A mentális distressz mutatók közül a hallgatók a stresszre adták a legtöbb pontszámot. A gyakoriságvizsgálat azt az eredményt mutatja, hogy a résztvevők 40,9\%-a a mérsékelt - súlyos - extrém súlyos tartományba tartoznak e tekintetben. A nemek közül a nők jóval magasabb stressz-szintet jeleznek. A Debreceni Egyetem hallgatóinak ( $\mathrm{N}=147)$ és a két nagyváradi egyetem hallgatóinak $(\mathrm{N}=90)$ az összehasonlítása során szignifikáns különbséget találtam a pszichés jóllét egyes összetevői közül az autonómia és az életcél területén. A mentális distressz mutatók közül pedig a stressz skálán mértem jelentős eltérést. Míg a Debreceni Egyetem hallgatói a mérsékelt, addig a két nagyváradi egyetem hallgatói az enyhe tartományba tartoznak a stressz tekintetében. A nagyváradi hallgatók átlageredménye jóval alacsonyabb, mint a $\mathrm{DE}$ hallgatóinak eredménye. A stressz skálán mért értékek közötti különbség szignifikáns $(\mathrm{p}=0,042)$. A konfliktuskezelési stratégiák alkalmazásában nem találtam jelen- 
tős különbséget a két ország fiataljai között: a hallgatók egyaránt az elkerülő stratégiát preferálják.

A vizsgálati eredményekből látszik, hogy a fiatalok már a felsőoktatásban eltöltött évek alatt számos stressz- és konfliktusforrásnak vannak kitéve, amelyeket nem tudnak megfelelő módon kezelni. Ezért a felsőoktatási intézmények egyik fontos feladata lenne a hallgatók lelki egészségének a védelme, mentálhigiénés gondozása, mellyel elérhető lenne a hallgatói jóllét növelése és a stresszszint csökkentése.

\section{Irodalomjegyzék}

1. Hazag A. - Major J. (2008): A hallgatói kiégés jelensége, medikusok lelki egészségvédelme, Mentálhigiéné és Pszichoszomatika, 9(4), pp. 305-322.

2. Hamvai CS. - Pikó B. (2009): A serdülők szubjektív jóllétét meghatározó társas tényezők a családban és az iskolában. Új Pedagógiai szemle, 4. 30 43.

3. Hunter J. P. - Csikszentmihályi M. (2003): The positive psychology of interested adolescents. Journal of Youth and Adolescence, 32. évf. 27-35.

4. Indries K. (2005): Vallásosság, Országos Epidemiológiai Központ, OLEF2003, Kutatási jelentés.

5. Kopp M. - Martos T. (2011):A magyarországi gazdasági növekedés és a társadalmi jóllét, életminőség viszonya, Magyar Pszichofiziológiai és Egészséglélektani Társaság, Budapest.

6. Lazányi K. (2011a): Mit nyújthat egy szakkollégium a felsőoktatásban tanuló hallgatóknak? Erdei Ferenc VI. Tudományos konferencia kiadványa, Kecskemét.

7. Lazányi K. (2011b): A társas támogatás szerepe és jelentősége a felsőoktatásban a diákszervezeti tagság kapcsán. In: Vállalkozásfejlesztés a XXI. században, Budapest, pp. 155-170.

8. Martos T. (2010): Életcélok és lelki egészség a Magyar társadalomban, Doktori $(\mathrm{PhD})$ értekezés, Semmelweis Egyetem, Budapest.

9. Móczár Á. (2012): Gyógypedagógus hallgatók társas támogatásának vizsgálata, Szakdolgozat, ELTE-BGGYK, Budapest.

10. Ryff C. (1989). "Happiness is everything, or is it? Exploration son the meaning of psychological well-being". Journal of Personality and Social Psychology, 57, 1069-1081.

11. Thomas K. W. - Kilmann R. H. (1974): Thomas-Kilmann conflict mode instrument. New York: Xicom. 


\section{Barth Anita}

Erdélyben születtem 1990-ben. A középiskolai tanulmányaimat Budapesten végeztem. A Debreceni Egyetem Egészségügyi Karára 2012-ben jelentkeztem diplomás ápoló szakra, ahol jelenleg negyedéves hallgató vagyok. A Debreceni Egyetem Tehetséggondozó Programjának 2013 óta vagyok a tagja. A diploma megszerzése után mesterképzésben szeretnék majd részt venni. 